\title{
Social Structure and Clearance Rates: The Effect of Neighborhood Characteristics on Aggravated Assault Case Outcome
}

Brad Silberzahn

Follow this and additional works at: https://researchrepository.wvu.edu/etd

\section{Recommended Citation}

Silberzahn, Brad, "Social Structure and Clearance Rates: The Effect of Neighborhood Characteristics on Aggravated Assault Case Outcome" (2015). Graduate Theses, Dissertations, and Problem Reports. 6643. https://researchrepository.wvu.edu/etd/6643

This Thesis is protected by copyright and/or related rights. It has been brought to you by the The Research Repository @ WVU with permission from the rights-holder(s). You are free to use this Thesis in any way that is permitted by the copyright and related rights legislation that applies to your use. For other uses you must obtain permission from the rights-holder(s) directly, unless additional rights are indicated by a Creative Commons license in the record and/ or on the work itself. This Thesis has been accepted for inclusion in WVU Graduate Theses, Dissertations, and Problem Reports collection by an authorized administrator of The Research Repository @ WVU. For more information, please contact researchrepository@mail.wvu.edu. 
Social Structure and Clearance Rates: The Effect of Neighborhood Characteristics on Aggravated Assault Case Outcome

\author{
Brad Silberzahn \\ Thesis submitted \\ to the Eberly College of Arts and Sciences \\ at West Virginia University \\ in partial fulfillment of the requirements for the degree of \\ Master of Arts in \\ Sociology \\ James Nolan, Ph.D., Chair \\ Jason Manning, Ph.D. \\ Joshua Woods, Ph.D. \\ Department of Sociology and Anthropology
}

Morgantown, West Virginia

2015

Keywords: clearance rates, social structure, aggravated assault, homicide, Donald Black, The Behavior of Law

Copyright 2015 Brad Silberzahn 


\section{ABSTRACT \\ Social Structure and Clearance Rates: The Effect of Neighborhood Characteristics on Aggravated Assault Case Outcome \\ Brad Silberzahn}

The ability of police to make an arrest for a crime is one of the most visible aspects of the criminal justice system. As a result, it is no surprise that clearance rates are one of the most commonly used measures of police effectiveness. Previous studies of clearance rates focus heavily on the clearance of homicide cases, as many researchers examine the effect of individual level characteristics on case outcomes. Using Donald Black's theory of law, which places an emphasis on social space, i.e., vertical and horizontal distances between victims and offenders, this study examines the effect of neighborhood characteristics on case outcome for the crime of aggravated assault. Logistic regression analysis $(\mathrm{N}=1575)$ indicates some support for Black's theory at the neighborhood level. However, the majority of variation in clearance rates appears to occur due to individual level factors. 


\section{TABLE OF CONTENTS}

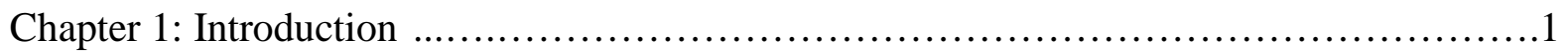

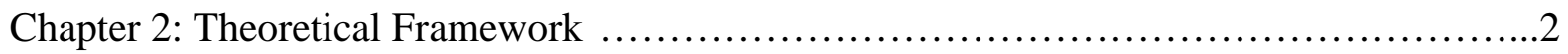

Chapter 3: Clearance Rate Literature ...............................................6

Chapter 4: Method of Analysis ................................................... 11

Chapter 5: Sample Description ................................................... 15

Chapter 6: Analysis ................................................................

Chapter 7: Findings .............................................................. 18

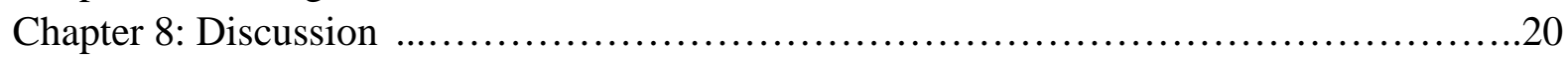

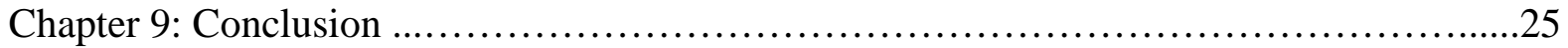

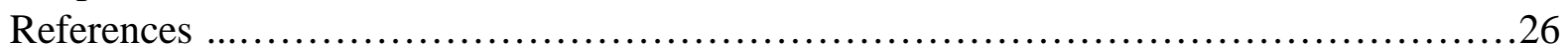

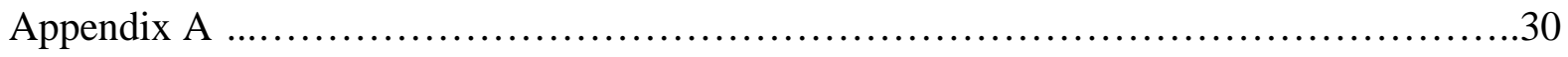




\section{Introduction}

Of all the aspects of the criminal justice system, arrests are one of the most visible actions in our society. The vast majority, if not all police departments and agencies use clearance rates (the number of crimes solved by arrest or exceptional means ${ }^{1}$ divided by the number of crimes reported) to notify the public, and evaluate themselves on their ability to enforce laws. As Cordner (1989) points out, clearance rates are one of the most common indicators of police investigative effectiveness. As a result, the ability of police to solve crimes plays a crucial role in the public's perception of the criminal justice system.

Given the advances in forensic and investigative technology, one would expect clearance rates to be at an all-time high. In the United States however, police fail to clear 53 percent of all violent crimes (FBI 2012). When solely examining homicides, recent statistics found that clearance rates have gone from approximately 90 percent in 1960 to 62 percent in 2012 (Federal Bureau of Investigation 2007; Federal Bureau of Investigation 2013). Due to the importance of a police officer's ability to solve crimes, an understanding of the factors that affect clearance rates is paramount to improve policing.

Among the literature on variations in clearance rates, two explanations are commonly used. Donald Black's (1976) theory of the behavior of law attributes variations in clearance rates to the social structure of a case, arguing that police may use some discretion in clearing homicide cases based upon social characteristics such as the relative status and relational distance of the parties involved. Critics such as Wolfgang (1958), Gottfredson and Hindelang (1979), and Klinger (1977) instead place an emphasis on the legal aspects of a case such as use of a weapon, body location, number of witnesses, and whether or not a concomitant felony occurred. When

\footnotetext{
${ }^{1}$ Examples of exceptional clearance include the death of the offender, a victim refusing to cooperate, and if the extradition of a suspect was denied.
} 
examining clearance rates, the systematic study of Donald Black's theory of law has resulted in mixed findings, with overall support being limited at best. Alternatively, the analysis of legal factors on case clearance has been more consistent and supportive.

Current clearance rate literature is limited for multiple reasons. Primarily, it is limited because of its disproportionate attention to homicides. Focusing only on homicides is problematic because homicide detectives are evaluated solely on their ability to solve a case. As noted by Puckett and Lundman (2003:175), “[w]hile it is possible that some homicide detectives are tempted to resort to extralegal factors to determine how hard to work particular cases, the singular importance of homicide clearances makes recourse to such factors unlikely.” In addition, only a limited number of studies have addressed the effect macro-level characteristics have on clearance rates. The current study contributes to clearance rate literature by analyzing the effect of neighborhood level characteristics on the clearance rates of aggravated assaults, a less serious crime in which officers are afforded a greater level of discretion than homicides.

The purpose of this research is to answer the question: does neighborhood social structure affect the likelihood of an aggravated assault case being cleared? In order to answer this question, logistic regression analysis using both incident-based data from a small mid-Atlantic city and census tract data from the United States Census Bureau will be used.

\section{Theoretical Framework}

In his book The Behavior of Law, Donald Black (1976), provides a highly testable theory of law. Black defines law as governmental social control, a phenomenon that occurs whenever state agents define and respond to deviant behavior (Black 1976:2). Examples of law include acts such as making an arrest, sentencing an individual to prison, interrogating a suspect, or investigating a crime. Black (1976:3) conceptualizes law as a quantitative variable, measurable 
by the amount of governmental authority brought to bear against an alleged deviant. Filing a report with the police, for example, is less law than being charged with a crime. Additionally, receiving the death penalty is more law than being found not guilty. Black's theory "contains theoretical formulations that predict and explain the quantity and style of law in various locations and directions in social space" (Black 1995:830), as defined by such factors as the social status of the parties involved and their social distance from one another. One kind of social distance, for example, is relational distance, as measured by the degree to which persons or groups participate in one another's lives. Intimates, such as spouses or cohabiting partners are relationally close, while those with little prior or ongoing interaction, such as strangers, are relationally distant. Black (1989) proposes that law varies directly with relational distance, meaning that a case among intimates is predicted to result in less law than a case among strangers. Consider that marital rape was not considered a crime in all fifty states until 1993, or that sexual assaults involving acquaintances are unlikely to be reported (Felson, Paré 2005).

Social status, the focus of this analysis, refers to one's position relative to others in a system of stratification. In The Behavior of Law, Black posits that social status is determined by indicators such as an individual's relative amount of material wealth, culture (as measured by education or other forms of cultural knowledge), respectability (defined by one's reputation for virtuous or deviant conduct), and organization (the capacity for collective action) ${ }^{2}$ For example, a convicted criminal has less respectability than someone who has never been accused or found guilty of a crime. Also, someone with a graduate or professional degree has a greater level of culture than a high school dropout. Lastly, someone protected by a union has more organization than someone who is self-employed. Black originally addressed each of these indicators and their relationship with law separately. However, as the theory has evolved, each indicator has become

\footnotetext{
${ }^{2}$ For a complete description, see The Behavior of Law (1976) by Donald Black.
} 
a part of the larger concept of social status. As Cooney (2009:186) states, "since the theory predicts identical status effects, it can be stated more concisely by collapsing the individual statuses into a single, composite status."

The following figure, taken from Black's (1989) book Sociological Justice, demonstrates the amount of law elicited by a case as a result of the social status of the parties involved.

Figure 1. Status Structure and Relative Attractiveness to Law

Status of Defendant

\begin{tabular}{cc|c|c|} 
& \multicolumn{2}{c}{ Low } & \multicolumn{1}{c}{ High } \\
\cline { 3 - 3 } Status of & High & 1 & 2 \\
Complainant & Low & 3 & 4 \\
\cline { 3 - 3 } & & &
\end{tabular}

Note: 1 represents the most law; 4 represents the least law.

As shown above, Black's theory of law contains the following propositions: (1)

Downward law is greater than upward law. In 1998 for example, the killing of a New York police officer by a civilian prompted an investigation from over 200 detectives (McAlary 1990). In comparison, Milton, Halleck, Lardner, and Albrecht (1977) found that the vast majority of citizen homicides by police officers are considered justified; and if a conviction does occur, punishment primarily consists of only a verbal or written reprimand of the act. (2) Law is greater among higher status individuals than lower status individuals. As the status of both participants increases, the "more likely the defendant is to be prosecuted, convicted, convicted of a more serious degree... and to receive a severe sentence" (Cooney 2009:37). For example, Sun and Payne (2004) found that police officers were more likely to provide assistance for individuals living in affluent neighborhoods. Consider the following excerpt from an ethnography of patrol units in an urban area where diminished effort by police officers due to a victim's status is evident. 
"A fight was clearly imminent, but that did not seem to bother the officers, they just wanted to get out of there. Ted (one of the officers) even remarked that the older black man (the alleged offender) was drunk and feeling "big." When I say a fight was imminent, I mean I thought they were going to start swinging while we were right there. As we drove off, Frank [Ted's partner] turned to me and said, "Did you hear them? Just like a bunch of Chimpanzees" (Black 1980:9). ${ }^{3}$

In this example, the police officers were dealing with poor, minority men in a neighborhood of high poverty. Thus it is presumable that the men involved were uneducated and lacked any material wealth. Therefore, these men occupy a position of lower status in comparison to the police officers.

While Black's theory focuses on individual level characteristics, he argues in his book The Manners and Customs of the Police, that his theory of law is applicable to macro analysis as well ${ }^{4}$. He states that, "the social characteristics of a neighborhood or community predict and explain the nature of the police work-if any that it will have" (Black 1980:5). Due to their attitudes toward lower status individuals, police officers may fail to work diligently to solve a case solely because of the location in which the call to service was made. This is clearly evident in the following statement from an officer describing a previous call he responded to that was known to be in an area occupied by lower class blacks.

"As we walked to the door of the run-down brick house. Harold [an officer] said, "I was here a month or so ago, and the husband came out with a shotgun," Gene [Harold's

\footnotetext{
${ }^{3}$ The racist view of these police officers, evident by the use of the term "chimpanzees" indicates the officers see these men as less respectable and thus lower status as a result of their skin color.

${ }^{4}$ In his 2010 interview "How Law Behaves," Donald Black states that he would "be more careful about extending the formulations in The Behavior of Law to a macroscopic level[.]" and that the primary focus of his theory is on the individual parties involved.
} 
partner] said nothing. Of course, none of us stood directly in front of the door. Gene tapped lightly at the storm door. There was no answer, but we could hear music inside and a light was on. Nevertheless, Gene didn't knock again, but said, 'Well, if they don't want to answer that's fine with me. Let's go.” So we did" (Black 1980:9).

The use of discretion based on social status can result in many unfortunate consequences. Clearance rates, the concern of this study, are no exception.

\section{Clearance Rate Literature}

Clearance rates are one of the most common indicators of police investigative effectiveness (Cordner 1989), and are one of the most commonly studied. The vast majority of literature addressing clearance rates, however, has focused its attention on homicides. Of studies addressing homicides, examinations of individual factors are the most common. Analysis of individual level factors has shown inconsistent results (Litwin 2004), with minimal support for Black's theory overall.

Numerous studies have used race as an indicator of status. Due to the fact that blacks and other minorities typically have less wealth and education than whites, Black's theory that law is greater among individuals of high status than individuals of low status leads us to expect that police will use less effort to solve cases involving minority victims. As a result, homicide clearance rates will be lower for cases involving minority victims as opposed to white victims. However, Regoeczi, Kennedy, and Silverman (2000) found that victim race did not have an effect on clearance rates. Whereas Litwin (2004) found that homicide cases involving Latino victims were 2.5 times less likely to be cleared than cases involving white victims. ${ }^{5}$ Taylor, Holleran, and Topalli (2009) found that 66 percent of homicide cases involving both a white

\footnotetext{
${ }^{5}$ It should be noted both Regoeczi et al. (2000) and Litwin (2004) did not account for offender race. However, Black's theory predicts that clearance rates will be lower for minority victim regardless of the race of the offender.
} 
offender and victim were cleared, whereas cases involving an African American victim and offender had a clearance rate of 72 percent, directly contradicting Black's theory.

Sex has also been used as a proxy measure of status, and has yielded similar inconsistencies. When applied to Black's theory of law, clearance rates for female victims are expected be lower than that of male victims because they generally occupy a position of lower status. However, multiple studies have concluded that sex had no effect on probability of clearance (Addington 2006; Litwin, 2004; Puckett and Lundman, 2003; Riedel and Rinehart 1996; Wellford and Cronin, 1999), or that female victims had a positive effect on case clearance (Addington 2006; Lee, 2005; Regoeczi et al. 2000; Roberts 2007). Opposite of Black's proposal, Roberts (2007) found that homicide cases involving female victims were 14 percent more likely to be cleared than homicides involving male victims. While these findings do not support Blacks theory that law is greater among individuals of high status than low status, it should be noted that a majority of studies fail to distinguish homicide circumstance. Consider homicide-suicides, incidents that require little to no investigative effort. Aderibigbe (1997) found that 96 percent of homicide-suicide victims were female. As a result, it is not surprising that cases of homicide involving female victims are cleared at the same rate or higher than homicides with male victims. Also, while differences in status as a result of sex are highly pronounced in places such as the Middle East, the United States contains a much larger proportion of women in high status positions. Therefore, sex is not a strong measure of status when analyzing U.S. data.

Age has also been used and tested as a proxy of status. Black's theory expects that clearance rates for homicide cases involving younger victims will be lower because younger individuals typically lack high levels of status such as personal wealth and occupational prestige. Test of the effect of age on homicide clearance has generally been more consistent than other 
non-legal characteristics, with prior research showing that homicides involving younger victims are more likely to be solved than homicides with older victims, a relationship opposite of that proposed by Black (Litwin 2004; Puckett and Lundman 2003; Riedel and Rinehart 1996; Roberts 2007).

While individual characteristics have mixed effects on clearance rates, the effect of victim offender relationship has been much more consistent. Although Black argues clearance rates will diminish as intimacy increases, previous literature has refuted this claim. For instance, Lee (2005) concluded that victims who were murdered by their partner or spouse were 59 percent more likely to have their cases solved than when the assailant was a non-intimate family member or friend. Similarly, findings from Marché (2004) indicate that homicides among individuals with no prior relationship reduce the probability of clearance by 48 percent.

Tests of Black's theory of law at the macro level are miniscule. Currently, we are aware of only a small number of studies that have tested at this level. Both Borg and Parker (2001) and Litwin (2004) examined the relationship between a city's unemployment rate and homicide clearance rates. A high unemployment rate is indicative of an area occupied by lower status individuals, and as a result, Black's theory of law expects that an area of high unemployment will have lower clearance rate compared to an area of low unemployment. However, findings from both Borg and Parker (2001) and Litwin (2004) conclude that the effect of an areas unemployment rate on clearance rates lacks any statistical significance.

In addition to the aforementioned tests, the effect of an areas level of educational attainment on clearance rates has also been examined. High educational attainment is more common among persons of high status as opposed to someone of low status. According to Black's theory of law, we can expect that areas of low educational attainment will have lower 
clearance rates than areas of high educational attainment. When operationalized as percentage of residents with at least a high school degree, educational attainment was found to have a positive effect on homicide clearance rates (Borg and Parker 2001). This finding supports Black's proposal that law is greater among higher status individuals. Findings from Litwin (2004) however, directly contradict Black's proposal. Litwin (2004) concludes that "a community area's percentage of residents ages 25 and older who have four or more years of college is not a significant predictor of a homicide case's clearance status" (Litwin 2004:344).

Previous examinations of Black's theory of law have also analyzed the relationship between home ownership and homicide clearance rates. According to Black's theory, police officers will respond with less effort to an area with a high number of vacant homes as compared to one with a high level of home ownership. This is because areas with vacant homes are typically occupied by lower status individuals and areas of high home ownership are usually occupied by individuals of high status. Borg and Parker (2001) found that the number of vacant homes in a city did not have a significant effect on clearance rates of homicides. Findings from Litwin (2004) on the other hand support Black's theory, concluding that home ownership was a statistically significant predictor of clearance.

Lastly, Puckett and Lundman (2003) created a proxy measure for victim social class, and also examined the effect of an area's racial composition on homicide clearance rate. Black's theory of law suggests that both victim social class and an area's racial composition should have a direct effect on clearance rates. Findings from both tests fail to support Black's theory. Alternatively, Pucket and Lundman (2003) concluded that census tract proxy measures for victim social class had no effect on clearance rates; and also that racial composition using census tract data failed to suggest any victim devaluing by police. 
As demonstrated above, tests of Black's theory of law have produced mixed results, with overall support being limited at best. Critics of Black's theory of law instead champion the notion that it is not the non-legal characteristics that dictate a case's outcome, but the legal, nondiscretionary factors instead. Non-discretionary factors used to explain variation in clearance rates include body location, weapon type, and number of witnesses. Previous tests of this perspective have proven to be much more consistent than those of Black's theory of law. For example, Litwin (2004) found cases involving a firearm to be 1.5 times less likely to be solved than cases that did not involve a firearm. Addington (2006), Puckett and Lundman (2003) also found a similar relationship between use of a contact weapon and likelihood of clearance. In addition, homicides involving a concomitant felony were found to be significantly less likely to be cleared (Lee 2005; Litwin 2004; Regoeczi et al. 2000; Riedel and Rinehart 1996). Lastly, Litwin (2004) concluded that cases involving an unknown circumstance are 94 times less likely to be cleared than those involving a general altercation.

While it is evident that this perspective has been well supported in the literature, it should be reiterated that the vast majority of empirical tests focus specifically on homicide cases. This is problematic for multiple reasons. Wolfgang (1958), Gottfredson and Hindelang (1977), and Klinger (1997) attest that homicide detectives work diligently to clear all homicide cases regardless of the characteristics of those involved and the setting in which it occurred. First and foremost, a homicide detective's performance is evaluated largely on whether or not a case is cleared (Ousey and Lee 2010). In addition, "because homicide garners substantial attention from the mass media and the general public, the police face external pressure to pursue each and every homicide case with similar vigor" (Ousey and Lee 2010:144). It is of special interest, then, to 
examine whether or not police discretion plays more of a factor in the clearance rates of less serious crimes.

In an analysis of clearance rates of violent crime incidents (murder, robbery, rape, and aggravated assaults), Taylor et al. (2009) found that cases were 3.9 percent less likely to be cleared if both the victim and offender were African American compared to cases involving whites. They go on to point out that while this percentage may appear to lack practical significance, "the pure number of cases [involving] victim race, particularly in combination with offender race, may be obscured through an emphasis on percentage differences" (Taylor et al. 2009:583). Therefore, with over 12,000 incidents, it is important to acknowledge that a small percentage difference can have adverse effects on a large number of people. A second study comparing clearance rates of homicides to aggravated assaults at the micro level found similar results. Roberts and Lyons (2009) found that aggravated assaults between whites were more likely to be cleared than blacks, which also supports Black's proposition that cases among higher status individuals will result in more law than cases among low status individuals. Roberts and Lyons (2009:315) also found that, "[v]ictim-offender racial dyads seem to matter more for less

serious offenses." Lastly, Weiss, Addington, and Nolan (in manuscript) concluded that non-fatal violent offenses among females are less likely to result in arrest than other gender dyad. These findings support Klinger's (1997), and Gottfredson and Hindelang's (1977) argument that homicide detectives are unable to exercise discretion due to the seriousness of the offense.

\section{Method of Analysis}

Logistic regression analysis will be used to answer the question: Does neighborhood social structure affect the likelihood of an aggravated assault case being cleared? It is hypothesized that: 
$\mathrm{H}_{1}$ : Clearance rates for aggravated assaults will be lower in low status neighborhoods than high status neighborhoods.

The following analysis uses data of aggravated assault cases $(n=1575)$ obtained from both NIBRS data from 2010-2013 at the agency level and the 2010 Census Demographic Profile. NIBRS data provides incident-level information for crimes reported to the police. Data collected for each incident includes offense type, location of incident, and characteristics of victims and offenders. This analysis focuses on incident-level data of one police agency whose jurisdiction covers a small mid-Atlantic city with a population of approximately 75,000 people. Using data from a single police agency provides a unique analysis because individual agencies have a standardized protocol of enforcement practices. Therefore, disparities in clearance rates can be attributed solely to differences in the characteristics of the individuals and neighborhoods officers are assigned to police. Data on the respective neighborhood characteristics for the location of each aggravated assault used in this analysis were extracted from census tract information in the 2010 Census Demographic Profile. The 2010 Census Demographic Profile, compiled by the United States Census Bureau provides neighborhood demographic characteristics determined by five year estimates (2006-2010) from the American Community Survey. Demographic data of each neighborhood includes employment rates, racial composition, occupational information, income, and educational attainment.

\section{Variables}

Dependent Variable:

The dependent variable in this analysis is the outcome of a case in which aggravated assault was the primary offense. Aggravated assault case outcome is being operationalized 
dichotomously, with (0) indicating an aggravated assault was not cleared by arrest or exceptional means ${ }^{6}$ and (1) indicating an aggravated assault was cleared by arrest or exceptional means.

As previously stated, clearance rates are "one of the most common indicators of police investigative effectiveness" (Cordner 1989). Thus, the outcome of a case is a reflection of the level of investigative effort used by police officers. Borg and Parker (2001:439) note that "the likelihood of clearing any specific crime is partially a function of the criminal justice resources expended toward its investigation." Therefore, clearance rates of aggravated assaults are an effective measure of law. ${ }^{7}$ In addition, focusing solely on aggravated assaults is beneficial because it provides an opportunity to evaluate police officers on their investigative effort of a less serious crime than the more commonly studied crime of homicide. Lastly, only cases in which aggravated assaults were the primary offense are being analyzed due to previous findings indicating that homicides cases involving a concomitant felony are more likely to be solved (Lee 2005; Litwin 2004; Regoeczi et al. 2000; Riedel and Rinehart 1996).

Independent Variable:

The independent variable for this analysis is neighborhood social status. Neighborhood social status is being measured by the following census tract measures taken from the 2010 Census Demographic Profile: Percentage of African American residents, natural log of median income, unemployment rate, percentage of vacant homes, and percentage of residents with a bachelor's degree or higher. Given their effectiveness as indicators of social status at the

\footnotetext{
${ }^{6}$ Four cases of aggravated assault are included in which the police identified a suspect but prosecution was declined. These exceptionally cleared cases are being included because the focus of this analysis is the actions of police officers. Therefore, although prosecution was declined, police officers completed their duty of identifying a suspect for arrest.

${ }^{7}$ One limitation to using clearance rates of NIBRS data is the exclusion of cases not reported by officers. As a result, it should be noted that cases in which officers failed to file a report are missing from this analysis.
} 
individual level, aggregate level measurements provide effective representation of neighborhood status as well.

As suggested by previous research (Cooney 2009), in addition to the individual indicators of neighborhood social status, a composite variable indicating overall neighborhood status is included in the analysis. Including a composite variable is beneficial for multiple reasons. A high correlation exists between race, income, and education. In addition, a neighborhood may have a high percentage of minorities who are highly educated, wealthy, and employed in well-respected positions such as professors, doctors, or lawyers. Therefore, a composite variable is more indicative of the neighborhoods status as a whole.

Overall neighborhood status is operationalized as follows: First, quartiles were determined for each measure of neighborhood social status listed above and recoded ordinally on a scale from 1-4. A value of 1 indicates the quartile of neighborhoods of the lowest status and 4 indicates neighborhoods of the highest status. Next, the sum of all five recoded indicator variables was taken, resulting in a total composite score for each neighborhood. The lower the score of the neighborhood, the lower its overall status.

Control Variables:

Given previous research, victim age, victim race, victim sex, victim-offender relationship, and presence of a firearm are used as control variables. Victim age is measured continuously, while victim sex, victim race, and presence of firearm are measured dichotomously. Victim sex is coded a (1) if the victim was a female, and (0) if male. Victim race is coded (1) if the victim was African American and (0) if the victim was white. Presence of firearm is coded (1) if a firearm was present and (0) if a firearm was not present. Victim-offender 
relationship will be operationalized nominally into the following categories: (1) Relationship was undetermined (2) offender was a stranger (3) victim knew offender.

\section{Sample Description}

As previously stated, 1575 aggravated assault cases are included in this analysis. Of the 1575 cases, 52 percent were cleared by arrest or exceptional means. The average victim was 31 years of age. Eighty-one percent of victims were African American and 61 percent were male. In 45 percent of aggravated assault cases, the relationship between victim and offender was undetermined. Seven percent of cases occurred between strangers, and in 48 percent of aggravated assault cases, the victim knew their assailant. Lastly, 24 percent of cases involved the use of firearm.

\begin{tabular}{|c|c|c|}
\hline \multicolumn{2}{|l|}{ Table 1: Descriptive Statistics of Neighborhoods in Analysis } & No23 \\
\hline Neighborhood Characteristic & Median & $1.7 \%-90 \%$ \\
\hline Percent African American & $77 \%$ & $1.1-14.1 \%$ \\
\hline Unemployment Rate & $9 \%$ & $1.3 \%-66.8 \%$ \\
\hline $\begin{array}{c}\text { Percentage of Residents with a } \\
\text { Bachelor's Degree or Higher }\end{array}$ & $12.2 \%$ & $6.6 \%-23 \%$ \\
\hline Percentage of Vacant Homes & $16 \%$ & $\$ 11,376-\$ 121,900$ \\
\hline Median Household Income & $\$ 31,892$ & \\
\hline
\end{tabular}

As shown above (Table 1), the majority of neighborhoods in this analysis are considered low status. The median household income of $\$ 31,892$ is more than $\$ 20,000$ less than the national median of $\$ 53,046$ (U.S. Census Bureau 2014). The neighborhoods are primarily occupied by African Americans, and the median percentage of residents with a Bachelor's degree or higher is less than half of the National Average of 28.8 percent for individuals over the age of 25 (U.S. Census Bureau 2014). The percentage of vacant homes is 3.4 percent higher than the national 
average of 12.6 percent (U.S. Census Bureau 2015). Lastly, the median unemployment rate of 9 percent is 3.4 percent higher than the national average of 5.6 percent (Bureau of Labor 2014).

\section{Analysis}

Three logistic regressions were used to examine the effect of neighborhood social structure on aggravated assault case outcome: (1) A nested model including only control variables (2) a model including individual neighborhood characteristics and (3) a model using a composite variable for overall neighborhood status ${ }^{8}$. Due to the fact that identical neighborhood characteristics are applied to a number of observations, clustered variance estimators are used to account for intragroup correlation (Rogers 1993).

As expected, the logistic regression testing the effects of individual neighborhood characteristics on the odds of aggravated assault case clearance indicated the possibility of multicollinearity. The relationship between a neighborhoods percentage of residents with a bachelor's degree or higher is especially noteworthy. Specifically, a strong negative relationship exists between a neighborhoods percentage of resident's with a bachelor's degree or higher and the unemployment rate $(\mathrm{r}=-.65 ; \mathrm{p}<.01)$. In addition, median household income and percentage of residents with a bachelor's degree or higher were found to have a strong positive relationship $(\mathrm{r}=.539 \mathrm{p}<.01)$. The relationship between cases involving a known assailant and aggravated assault case outcome was also found to be significantly correlated $(r=.60 ; p<.01)$.

Although the variables were highly correlated, overall assessment of the model proved acceptable. A test for multicollinearity resulted in tolerance values no greater than .1 and variation inflation factors $\leq 2.29$, well below the suggested limit of 10 . Furthermore, a Pearson's $\mathrm{X}^{2}$ Goodness of fit test failed to reject the model (Prob $\left.>\mathrm{chi}^{2}=.2949\right)$. Including neighborhood

\footnotetext{
${ }^{8} \mathrm{~A}$ fourth regression testing for interaction effects between overall neighborhood status and significant control variables was examined. However, none were found to have any statistical significance. For regression output, see appendix (pg.30).
} 
characteristics in the regression model increased the Pseudo $\mathrm{R}^{2}$ from .3677 to .3769 . Although this increase was minimal, a likelihood ratio test indicates that including the neighborhood characteristics results in a better fitting model $(\mathrm{p}<.01)$

As previously stated, the third model used in this analysis examines the relationship between a neighborhoods overall status and the odds of aggravated assault case clearance. Using a composite variable for overall status reduced correlation among variables to a minimum. Testing for multicollinearity resulted in tolerance values less than .1 and variation inflation factors no greater than 1.31. Furthermore, A Pearson's $X^{2}$ Goodness of Fit test failed to reject model $2\left(\right.$ Prob $\left.>\operatorname{chi}^{2}=.2662\right)$. Lastly, including the composite variable for overall neighborhood status slightly reduced the Pseudo $\mathrm{R}^{2}$ from .3769 to .3711 . 


\section{Findings}

Table 2: Logistic Regression Results of Factors Affecting Aggravated Assault Case Outcome $\mathrm{N}=1575$

Dependent Variable: Aggravated Assault Case Outcome: (1) Arrest (0) No Arrest

\begin{tabular}{|c|c|c|c|}
\hline Independent Variables & $\begin{array}{c}\text { (1) } \\
\text { Odds Ratios } \\
\text { Reported }\end{array}$ & $\begin{array}{c}(2) \\
\text { Odds Ratios } \\
\text { Reported }\end{array}$ & $\begin{array}{c}\text { (3) } \\
\text { Odds Ratios } \\
\text { Reported }\end{array}$ \\
\hline Percent African American & & $2.72(.98)^{* *}$ & \\
\hline Unemployment Rate & & $.02(.068)$ & \\
\hline $\begin{array}{c}\text { Percentage of Residents with } \\
\text { a Bachelor's Degree or } \\
\text { Higher }\end{array}$ & & $.816(.97)$ & \\
\hline Percentage of Vacant Homes & & $.0119(.017)^{* *}$ & \\
\hline $\begin{array}{l}\text { Log of Median Household } \\
\text { Income }\end{array}$ & & $1.53(.264)^{*}$ & \\
\hline Overall Status & & & $1.057(.025)^{*}$ \\
\hline Victim Age & $1.002(.0049)$ & $1.003(.049)$ & $1.002(.005)$ \\
\hline African American Victim & $1.02(.148)$ & $.991(.131)$ & $1.08(.15)$ \\
\hline Female Victim & $1.43(.25)^{*}$ & $1.455(.262)^{*}$ & $1.45(.25)^{*}$ \\
\hline Victim Knew Offender $^{1}$ & $21.26(2.74)^{* *}$ & $21.857(2.917)^{* *}$ & $21.56(2.825)^{* *}$ \\
\hline Offender Was a Stranger ${ }^{1}$ & $16.86(3.73)^{* *}$ & $17.415(4.138)^{* *}$ & $16.34(3.71)^{* *}$ \\
\hline Gun Involved & $.46(.049)^{* *}$ & $.443(.047)^{* *}$ & $.45(.047)^{* *}$ \\
\hline Constant & $.20(.046)^{* *}$ & $.004(.005)^{* *}$ & $.093(.038)^{*}$ \\
\hline Pseudo $\mathrm{R}^{2}$ & .3677 & .3769 & .3711 \\
\hline
\end{tabular}

Note: *Relationship significant at .05 level.

*** Relationship significant at .01 level.

${ }^{1}$ Relationship Undetermined is reference group. 
Table 2 illustrates the logistic regression results of models 1, 2, and 3. Analysis of the nested model (model 1) resulted in many significant findings. Specifically, the odds of clearing aggravated assault cases involving female victims are roughly 1.4 higher than cases involving male victims $(\mathrm{p}<.05)$. Victim offender relationship also had a drastic effect on case outcome. The odds of case clearance are 21 times higher for cases in which victims knew their assailants $(\mathrm{p}<.01)$ than cases in which the victim offender relationship was undetermined, and roughly 4 times higher than when the offender was a stranger $(\mathrm{p}<.01)$. Lastly, the odds of case clearance for aggravated assault are .46 times lower when a firearm is used $(\mathrm{p}<.01)$

When including the independent status indicators in the regression (model 2), all control variables maintained their statistical significance, as well as relatively the same effect on case outcome. Many of the neighborhood characteristics were also found to have a significant effect on case outcome. For every one percent increase in the number of African Americans living in a neighborhood, the odds of an aggravated assault case being solved increases by 172 percent $(\mathrm{p}<.01)$. The percentage of vacant homes in a neighborhood was also found to have a significant effect on case outcome. Specifically, the odds of an aggravated case being cleared decreases by almost 98 percent with every one percent increase in a neighborhoods amount of vacant homes $(\mathrm{p}<.01)$. In addition to racial composition and educational attainment, income was also found to have a significant effect on case outcome. A one unit increase in the natural log of a neighborhoods median income increases the odds of an aggravated assault case being cleared by 53 percent $(\mathrm{p}<.05)$. A neighborhood's unemployment rate and percentage of residents with a bachelor's degree or higher were not found to have a significant effect on case outcome.

Testing the effect overall neighborhood status on aggravated assault case outcome (model 3) indicates that a neighborhoods overall status has a significant effect. A one unit increase in a 
neighborhood's overall status increases the odds of an aggravated assault case being cleared by 5.7 percent $(\mathrm{p}<.05)$.

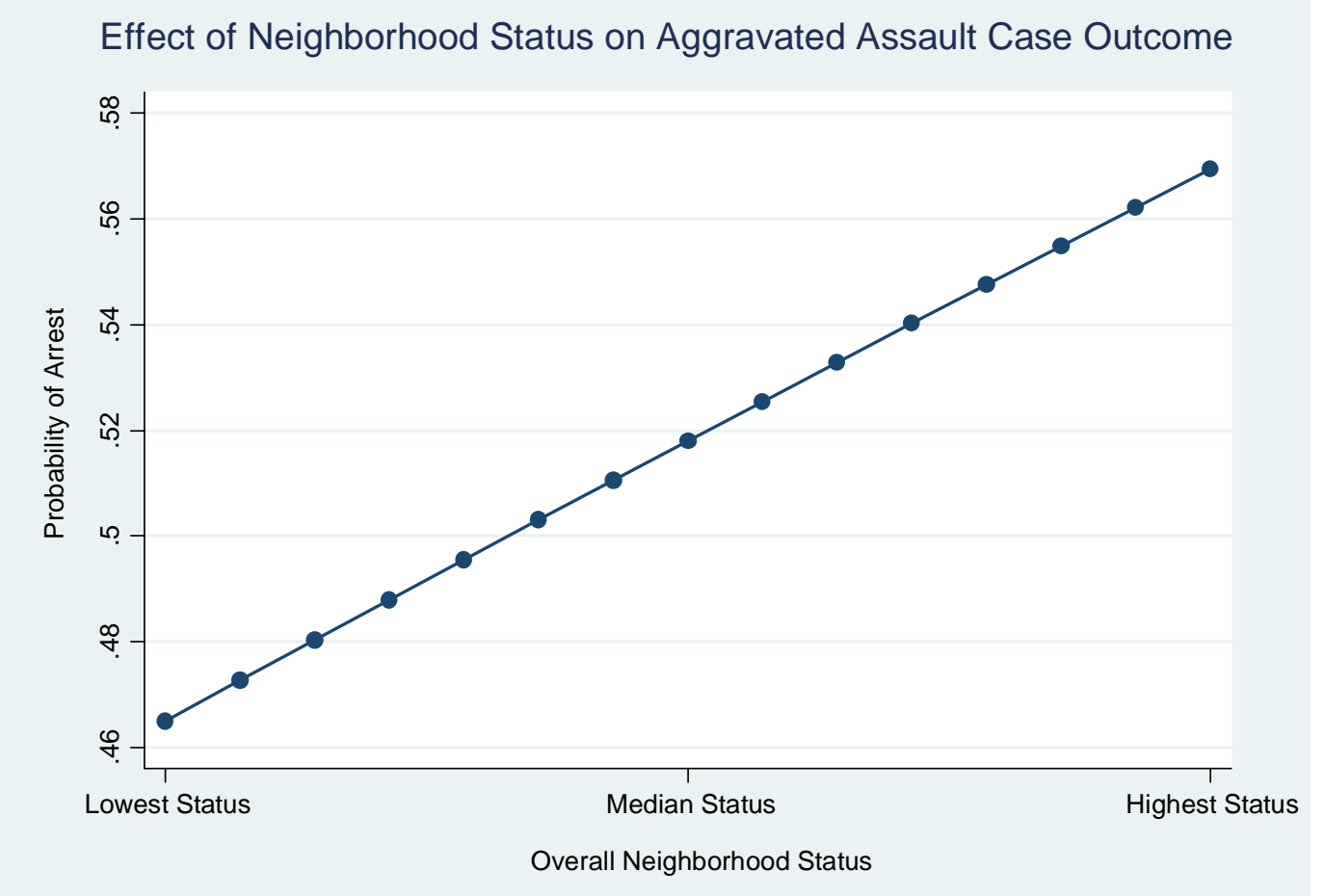

\section{Figure 2}

Figure $2^{9}$ illustrates the relationship between overall neighborhood status and likelihood of case clearance. It is predicted that an aggravated assault occurring in the lowest status neighborhood has a 46.4 percent chance of being cleared. Whereas an aggravate assault occurring in the highest status neighborhood has a 57 percent chance of being cleared.

\section{Discussion}

Previous tests of Black's theory of law, which proposes that law is greater among high status individuals than low status individuals, have produced inconsistent findings (Litwin 2004). Analysis of the effects of the independent neighborhood status indicators on the odds of

\footnotetext{
${ }^{9}$ The effect of neighborhood status on aggravated assault case outcome was calculated with all other variables at their means.
} 
aggravated assault case clearance resulted in a similar outcome, with findings offering both support as well as refuting Black's theory of law.

In support of Black's theory, a neighborhood's percentage of vacant homes was found to have an inverse relationship with the aggravated assault case outcome, decreasing the odds of clearance by 98 percent with every one percent increase $(\mathrm{p}<.01)$. While this finding is consistent with Litwin's (2004) analysis of homicide clearance, it contradicts Borg and Parker's (2001) conclusion that the number of vacant homes in a city did not have a significant effect on homicide case outcome.

The natural log of a neighborhood's median household income had a direct effect on the odds of aggravated assault case clearance. Specifically, a one unit increase in a neighborhoods median income increases the odds of case clearance by 53 percent $(\mathrm{p}<.05)$. While this finding supports Black's theory of law, it contradicts previous research by both Puckett and Lundman (2003) and Litwin (2004) which found that neighborhood income had no effect on homicide clearance rates.

Opposite of the relationship proposed by Black however, the percentage of African Americans in a neighborhood was found to have a strong positive effect on case outcome, with every one unit increase resulting in an increase in the odds of clearance by 172 percent $(\mathrm{p}<.01)$. Similarly, Taylor et al. (2009) found that 72 percent of cases involving an African American victim and offender were solved compared to only 66 percent of cases involving whites. However, previous literature on the effect of race is no more consistent than other independent status indicators. For example, Regoeczi et al. (2000) concluded that victim race had no effect on clearance rates. 
Also inconsistent with Black's theory, the effect of a neighborhood's unemployment rate on case outcome lacked any statistical significance. While this finding refutes Black's proposal that law is greater among individuals of high status, it is consistent with previous literature (Borg and Parker 2001; Litwin 2004).

Lastly, results from this analysis indicate that educational attainment did not have a significant effect on aggravated assault case outcome. Borg and Parker (2001) found a similar relationship when operationalizing educational attainment as the percentage of residents with at least a high school diploma. Litwin (2004) on the other hand argues that educational attainment is not a significant predictor.

Given the mixed findings from this research as well as from previous literature, it is clear that the effect of neighborhood characteristics on both aggravated assault as well as homicides are largely inconsistent. Specific to this analysis, examination of the effects of independent neighborhood status indicators on aggravated assault case clearance (model 1) proved inconclusive.

Although findings from model 1 were inconclusive, findings from model 2 indicate that a neighborhood's overall status directly effects the odds of aggravated assault case clearance. This finding offers strong support for Black's theory that law is greater among individuals of high status. As previously stated, a composite variable provides a more accurate measure of a neighborhood as a whole because it takes multiple aspects into account. A primarily white neighborhood or one with a high proportion of college graduates is not automatically high status, just as a primarily African American neighborhood is not automatically low status. Rather it is all of these aspects taken together that provides a more accurate representation. As a result, the finding from this research indicating that a one unit increase in a neighborhood's overall status 
increases the odds of an aggravated assault case being cleared by 5.7 percent $(\mathrm{p}<.05)$ supports the hypothesis that clearance rates for aggravated assaults will be lower in low status neighborhoods than high status neighborhoods.

While findings from this analysis indicate that neighborhood social structure does have an effect on aggravated assault case outcome, it must be taken into context. Although significant, neighborhood characteristics and overall status play a minimal role in case outcome in comparison to individual and case level characteristics. For example, a neighborhood's percentage of African Americans had the strongest effect on case outcome, increasing the odds of clearance by $172 \%(\mathrm{p}<.01)$. Whereas the odds of case clearance are 21 times higher for aggravated assaults involving a victim who knew their assailant as opposed to when the relationship was underdetermined $(\mathrm{p}<.01)$, and four times greater than when the assailant was a stranger $(\mathrm{p}<.01)$. Also, the odds of case clearance are $56 \%$ lower for aggravated assaults involving the use of a firearm $(\mathrm{p}<.01)$, whereas overall neighborhood status reduces the odds of arrest by only 5.7 percent for every one unit increase in a neighborhoods overall status $(\mathrm{p}<.05)$. In addition, including neighborhood characteristics resulted in a miniscule increase in the Pseudo $\mathrm{R}^{2}$ of the models. Specifically, the Pseudo $\mathrm{R}^{2}$ of the model increased from .3677 to .3767 when adding individual neighborhood characteristics, and from .3677 to .3711 when using overall neighborhood status. Furthermore, introducing neighborhood characteristics resulted in relatively zero change in the effect of individual level characteristics on aggravated case outcome. These findings indicate a majority of the variation in aggravated assault case outcome are caused by individual characteristics, and is consistent with Black's statement that he would "be more careful about extending the formulations in The Behavior of Law to a macroscopic level[..]" and that the primary focus of his theory is on the individual parties involved (Black 2010:43). 
Although it produced many significant findings, it should be noted that this research is not without its limitations. Arguably the biggest weakness of using NIBRS data is that only crimes in which a report is filed by the police are included. Thus, any cases of aggravated assault that were deemed insignificant by the responding officer were omitted from this analysis. Another limitation of this research is that only data from one police agency is examined. Although the area being analyzed is representative of a majority of urban communities in the United States, it remains to be seen if neighborhood social structure has the same effect in other areas such as rural communities. Lastly, when examining factors that affect clearance rates, the police community relationship present in poor minority communities needs to be acknowledged. In these communities, individuals who communicate and provide information to the police are sometimes threatened and even receive physical harm as a result of their cooperation. Therefore, "the potential of being stigmatized as a snitch [could] certainly influence reporting decisions" (Woldoff and Weiss 2010:185). In addition to the threat of harm, many poor minorities distrust the police, and will not cooperate or provide information because they do not see the criminal justice system as legitimate (Tyler 2003). As a result, the difficulty of solving a case needs to be taken into account. For example, a cop may work diligently to solve an aggravated assault committed by a stranger but fail to determine a suspect regardless of the effort put into the investigation. Due to these limitations, it is suggested that future research utilize different types of data such as interviews, surveys, and participant observation in both urban and rural communities to determine not only the true cause of disparities in clearance rates for wide range of crimes, but also to see if the same patterns exist in a multitude of settings. 


\section{Conclusion}

The previous analysis examined the relationship between a neighborhood's social structure and aggravated assault case outcome. Consistent with previous literature, test of the effect of independent status indicators such as median income, racial composition, and percentage of vacant homes resulted in mixed findings, both refuting and offering support for Black's theory that law is greater among individuals of high status than individuals of low status. While test of individual status indicators proved inconclusive, overall neighborhood status was found to have a direct effect on case outcome. Specifically, a one unit increase in overall neighborhood status increases the odds of aggravated assault case clearance by 5.7 percent $(\mathrm{p}<.05)$. This finding supports the hypothesis that clearance rates will be lower in low status neighborhoods than high status neighborhoods. Although this finding offers support for Blacks theory of law, the majority of disparities in clearance rates appear to be caused by individual and case level characteristics such as victim sex, victim offender relationship, and whether a not a firearm was used. 


\section{References}

Addington, Lynn A. 2006. "Using National Incident-Based Reporting System Murder Data to Evaluate Clearance Predictors." Homicide Studies 10(2):140-152.

Aderibigbe, Yekeen A. 1997. "Violence in America: A Survey of Suicide Linked to Homicides," Journal of Forensic Sciences 42(4):662-665.

Black, Donald. 1976. The Behavior of Law. New York, NY: Academic Press.

Black, Donald. 1980. The Manners and Customs of the Police. New York, NY: Academic Press.

Black, Donald. 1989. Sociological Justice. New York, NY: Oxford University Press.

Black, Donald. 2010. "How Law Behaves: An interview with Donald Black.” International Journal of Law, Crime, and Justice 38(1):37-47.

Borg, Marian J., and Karen F. Parker. 2001. "Mobilizing Law in Urban Areas: The Social Structure of Homicide Clearance Rates.” Law \& Society Review 35(2):435-466.

Cooney, Marc. 2009. Studies in Pure Sociology: Is Killing Wrong? : A Study in Pure Sociology. Charlottesville, VA: University of Virginia Press.

Cordner, Gary W. 1989. "Police agency size and investigative effectiveness.” Journal of Criminal Justice 17(3):145-155.

Federal Bureau of Investigation. 2007. Uniform Crime Reports. U.S. Department of Justice. U.S. Government Printing Office.

Federal Bureau of Investigation. 2013. Uniform Crime Reports. U.S. Department of Justice. U.S. Government Printing Office.

Felson, Richard and Paré, Paul-Philippe. 2005. “The Reporting of Domestic Violence and Sexual Assault by Nonstrangers to the Police.” U.S. Department of Justice Final Report. 
Gottfredson, Michael R., and Michael J. Hindelang. 1979. “A Study of Behavior of Law.” American Sociological Review 44(1):3-18

Klinger, David A. "Negotiating Order in Patrol Work: An Ecological Theory of Police Response to Deviance." Criminology 35(2):227-306.

Lee, Catherine. 2005. "The value of life in Death: Multiple Regression and Event History Analyses of Homicide Clearance in Los Angeles County.” Journal of Criminal Justice 33(6):527-534.

Litwin, Kenneth J. 2004. “A Multilevel Multivariate Analysis of Factors Affecting Homicide Clearances." Journal of Research in Crime and Delinquency 41(4):327-351.

Marché, Gary E. 1994. “The Production of Homicide Solutions: An Empirical Analysis.” American Journal of Economics and Sociology 53(4):385-401

McAlary, Mike. 1990. Cop Shot: The True Story of a Murder That Shocked the Nation. New York, NY: Berkley Publishing Group.

Milton, Catherine, James Wahl Halleck, James Lardner, and Gary L. Albrecht. 1977. Police Use Of Deadly Force. Washington, D.C. Police Foundation.

Ousey, Graham C., and Mathew R. Lee. 2010. “To Know the Unknown: The Decline in Homicide Clearance Rates, 1980-2000.” Criminal Justice Review 35(2):141-158.

Puckett, Janice L. and Richard J. Lundman. 2003. "Factors Affecting Homicide Clearances: Multivariate Analysis of a More Complete Conceptual Framework.” Journal of Research in Crime and Delinquency 40(2):171-193.

Riedel, Marc and Tammy A. Rinehart. 1996. "Murder Clearances and Missing Data.” Journal of Crime and Justice 19(2):83-102. 
Rogers, William H. 1993. "Regression standard errors in clustered samples.” Stata Technical Bulletin 13: 19-23. Reprinted in Stata Technical Bulletin Reprints, vol. 3, 88-94.

Sun, Ivan Y. and Brian K. Payne. 2004. "Racial Differences in Resolving Comparison between Black and White Police Officers." Crime and Delinquency 50(4):516-541.

Regoeczi, Wendy C., Leslie W. Kennedy, and Robert A. Silverman. 2000 “Uncleared Homicides A Canada/United States Comparison." Homicide Studies 4(2):135-161.

Roberts, Aki. 2007. "Predictors of homicide clearance by arrest: An event history analysis of NIBRS incidents. Homicide Studies 11(2):82-93.

Roberts, Aki and Christopher J. Lyons. 2009. "Victim-Offender Racial Dyads and Clearance of Lethal and Nonlethal Assault." Journal of Research in Crime and Delinquency 43(6):301-326.

Taylor, Terrance J., David Holleran and Volkan Topalli. 2009. "Racial Bias in Case Processing: Does Victim Race Affect Police Clearance of Violent Crime Incidents?’ Justice Quarterly 26(3):562-591.

Tyler, Tom R., 2003. Procedural Justice, Legitimacy, and the Effective Rule of Law. Crime and Justice 30:283-357

U.S. Bureau of Labor Statistics. 2014 QuickFacts.

U.S. Census Bureau. 2014. QuickFacts.

U.S. Census Bureau. 2015. U.S. Census Bureau News.

Weiss, Karen, Lynn A. Addington, and James Nolan. 2015. Is gender a discretionary factor in reporting or arrests of non-fatal violent crime? Manuscript in preparation.

Wellford, Charles and James Cronin. 1999. An Analysis of Variables Affecting the Clearance of Homicides: A Multistate Study. Washington, DC: Justice Research and Statistics Association.

Woldoff, Rachael A. and Karen Weiss. 2010. “Stop-Snitchin': Exploring Definitions of The Snitch and Implications for Urban Black Communities.” Journal of Criminal Justice and Popular Culture 17(1):184-223. 
Wolfgang, Marvin E. 1958. Patterns in Criminal Homicide. Philadelphia: University of Pennsylvania Press. 
Appendix A:

Logistic Regression Results of Interaction Effects on Aggravated Assault Case Outcome
\[ \mathrm{N}=1575 \]
Dependent Variable: Aggravated Assault Case Outcome: (1) Arrest (0) No Arrest

\begin{tabular}{|c|c|}
\hline Independent Variables & $\begin{array}{c}\text { (1) } \\
\text { Odds Ratios Reported }\end{array}$ \\
\hline Overall Status & $1.017(.0205)$ \\
\hline Victim Age & $1.002(.005)$ \\
\hline African American Victim & $1.078(.158)$ \\
\hline Female Victim & $.545(.410)$ \\
\hline Victim Knew Offender $^{1}$ & $19.23 * *(8.27)$ \\
\hline Offender was a Stranger ${ }^{1}$ & $6.63 *(6.17)$ \\
\hline Gun Involved & $.55(.18)$ \\
\hline Female Victim \& Overall Status & $1.08(.06)$ \\
\hline Known Offender \& Overall Status ${ }^{1}$ & $1.01(.032)$ \\
\hline Offender was a Stranger \& Overall Status ${ }^{1}$ & $1.07(.073)$ \\
\hline Gun Involved \& Overall Status & $.98(.03)$ \\
\hline Constant & $.154 * *(.046)$ \\
\hline Pseudo $\mathrm{R}^{2}$ & .373 \\
\hline
\end{tabular}

Note: *Relationship significant at .05 level.

**Relationship significant at .01 level.

${ }^{1}$ Relationship Undetermined is reference group. 